\title{
Identifikasie en beskrywing van 'n onbekende Spinitectus sp. van Clarias gariepinus ingesamel in die Vaaldam, Suid-Afrika
}

\section{Outeurs: \\ Lucinda Austin, \\ QM Dos Santos, \\ A Avenant-Oldewage \\ Affiliasie: \\ Departement Dierkunde, Universiteit van \\ Johannesburg \\ Posbus 524, Auckland Park, 2006 \\ Korresponderende outeur: L Austin \\ E-pos: \\ lucinaustin@gmail.com}

Hoe om hierdie artikel aan te haal:

Lucinda Austin, QM

Dos Santos, A Avenant-

Oldewage, Identifikasie

en beskrywing van ' $n$

onbekende Spinitectus

$s p$. van Clarias gariepinus

ingesamel in die

Vaaldam, Suid-Afrika,

Suid-Afrikaanse Tydskrif

vir Natuurwetenskap en

Tegnologie 38(1) (2019).

https://doi.org/10.36303/

SATNT.2019.38.1.757

Kopiereg:

(C) 2019. Authors.

Licensee: Die Suid-

Afrikaanse Akademie vir

Wetenskap en Kuns.

Hierdie werk is onder die Creative Commons Attribution License gelisensieer.
Identification and description of a Spinitectus sp. collected from Clarias gariepinus in the Vaal Dam, South Africa: Spinitectus is a genus of parasitic nematodes. The morphology, morphometrics and molecular distinctness of specimens collected in the Vaal Dam were compared with other African species to determine their identity. Limited correlation with other species was observed. More information is needed to accurately identify or describe this species.

Spinitectus is 'n genus van parasitiese nematode wat aan die familie Rhabdochonidae behoort, wat gekenmerk word deur die teenwoordigheid van ringe skerp stekels wat posteriorwaarts in grootte verklein. Tydens standaard parasitologiese ondersoeke in die Vaaldam, Suid-Afrika (Maart 2018), is agt Spinitectus-wurms ingesamel van Clarias gariepinus. Slegs twee spesies is in Suid-Afrika bekend en albei is in die Kruger Nasionale Park ingesamel: Spinitectus petterae (Krokodilrivier) van C. gariepinus en Spinitectus polli (Sabierivier) van Synodontis zambezensis. Die genus is nog nie tevore in die Vaalrivier aangeteken nie. Die doel van hierdie studie is om die morfologie, morfometrie en molekulêre kenmerke van die wurms wat in die Vaalrivier ingesamel is met die ander Afrika-spesies te vergelyk en hulle identiteit te bepaal. Met behulp van ligmikroskopie is die wurms met anhidriese gliserol opgehelder, bestudeer en daarna met ander Afrika-spesies vergelyk. Verskille tussen die skerp stekels en lengteverhoudings van strukture is vir die vergelykings gebruik. Een wurm is met behulp van skandeerelektronmikroskopie met heksametieldisilasaan (HMDS) gedroog om sy eksterne morfologie te bestudeer. Onderskeidende strukture wat opgemerk is, was die kefaliese en kaudale papille, die vorm van die pseudolabia en die plasing van die stekelringe. Die klein ribosomale subeenheid (18S) van rDNS is gebruik om die identiteit van die wurms te bepaal. Die ingesamelde spesie was geneties die naaste verwant aan S. petterae, maar die assosiasie is swak ondersteun en hulle kon geneties onderskei word. Uitsteeksels teenwoordig op die wyfies was soortgelyk aan S. polli en S. petterae. Die lengtes van die wurm voor die vulva teenoor die lengte na die anus was soortgelyk aan Spinitectus maleficius, Spinitectus allaeri en $S$. petterae. Die spikulum-grootte was soortgelyk aan S. petterae, S. polli en Spinitectus minusculus. Weens ' $n$ beperkte verband tussen die genetiese en morfologiese resultate van die ingesamelde wurms van die Vaaldam en Spinitectus-spesies wat in ander gebiede in Afrika ingesamel is, is meer inligting derhalwe nodig om hierdie nematode akkuraat te identifiseer of moontlik as 'n nuwe spesie te beskryf.
Nota: 'n Seleksie van referaatopsommings: Studentesimposium in die Natuurwetenskappe, 25-26 Oktober 2018, SA Akademiegebou, Pretoria, Suid-Afrika. Gasredakteurs: Prof Rudi Pretorius (Departement Geografie, Universiteit van Suid-Afrika); Prof Chris Swanepoel (Departement Besluitkunde, Universiteit van Suid-Afrika); Me Andrea Lombard (Departement Geografie, Universiteit van Suid-Afrika) 